\title{
ANALISA KINERJA ALAT PENUKAR KALOR JENIS PIPA GANDA
}

\author{
Oleh \\ Audri Deacy Cappenberg \\ Program Studi Teknik Mesin Universitas 17 Agustus 1945 Jakarta
}

\begin{abstract}
ABSTRAK
Pengujian Alat Penukar Panas Jenis Pipa Ganda Dan Optimasi Kinerjanya. Pengujian dilaksanakan dalam beberapa tahap dimana ada parameter yang divariasikan ( Gvc, Gvh, dan Th) dan ada parameter yang konstant (Tc). Dari hasil pengujian dan perhitungan diperoleh koefisien perpindahan panas menyeluruh (U) dengan menggunakan metode LMTD sebesar $3024 \mathrm{~W} / \mathrm{m}^{2}{ }^{\circ} \mathrm{C}$ dan yang menggunakan metode NTU sebesar $1814 \mathrm{~W} / \mathrm{m}^{2}{ }^{\circ} \mathrm{C}$.
\end{abstract}

Kata kunci: Sistem pengoperasian, Optimasi, Perpindahan panas me nyeluruh

\begin{abstract}
Testing of heat exchange double pipe type and optimization performance. Tests carried out in several stages with varied parameters (GVC, gvh, and Th) and there is a constant parameter (Tc). Based on results of tests and calculations, the overall heat transfer coefficient (U) using the LMTD method for $3024 \mathrm{~W} / \mathrm{m}^{2}{ }^{\circ} \mathrm{C}$ and the NTU method of $1814 \mathrm{~W} / \mathrm{m} 2{ }^{\circ} \mathrm{C}$.
\end{abstract}

Keywords: Operating System, Optimization, Heat transfer

\section{PENDAHULUAN}

Alat penukar kalor (heat exchanger) adalah alat yang digunakan untuk memindahkan panas antara dua fluida. Proses perpindahan panas tersebut dapat terjadi secara langsung, dimana fluida yang akan dipanaskan bercampur dengan fluida pemanasnya (tanpa ada pemisah) dalam suatu bejana, maupun secara tidak langsung dimana fluida pemanasnya tidak berhubungan secara langsung dengan fluida pemanasnya. Jadi proses perpindahan panas mempunyai media perantara misalnya pipa, plat atau peralatan jenis lainnya.

Penukar kalor merupakan suatu peralatan mesin yang amat penting, baik dalam sebuah sistem pembangkit tenaga, proses-proses industri, media transportasi, maupun dalam bidang pendidikan.

Untuk memahami berbagai proses perpindahan panas yang terjadi, maka selain teoriteori dasar dan terapan yang telah diberikan, maka perlu adanya suatu alat penukar kalor sebagai media dalam praktikum, sehingga berbagai proses perpindahan panas dapat dipahami dengan lebih baik. Untuk maksud tersebut, maka telah dibuat suatu alat penukar kalor tipe 
pipa ganda. Alat ini telah lama dibuat, tapi belum digunakan dalam praktikum, karena belum diujicobakan. Untuk itu akan dilaksanakan uji coba, sekaligus melakukan berbagai perhitungan yang berhubungan dengan sistem pengoperasian serta kinerja alat tersebut, sehingga dapat bekerja secara optimal dan selanjutnya dapat dimanfaatkan secara maksimal di laboratorium.

Dalam perancangannya, alat penukar kalor ini menggunakan tipe pipa ganda, aliran fluida searah dengan fluida yang digunakan adalah air . Temperatur masuk pada sisi dingin $27^{\circ} \mathrm{C}$ laju a liran masa $0.4 \mathrm{~kg} / \mathrm{s}$, temperatur masuk pada sisi panas $65^{\circ} \mathrm{C}$ laju aliran masa $0.15 \mathrm{~kg} / \mathrm{s}$.

\section{Metode yang digunakan dalam penelitian ini adalah :}

1. studi literatur memanfaatkan tulisan-tulisan ilmiah dari jurnal terkait tentang perpindahan panas dan alat penukar kalor, atikel dan tulisan ilmiah di internet dan buku-buku referensi lainnya

2. Pengujian dan pengambilan data serta perhitungan dan pembahasan data pengujian dan analisis dengan menggunakan LMTD dan NTU

\section{Landasan Teori}

Energi berpindah dari dan ke sistem, perpindahan ini terjadi karena ada perbedaan antara sistem dan sekeliling. Perpindahan energi dapat terjadi dalam bentuk panas dan kerja. Proses peripindahan energi akan terus berlangsung selama belum terjadi keseimbangan, baik tekanan, temperatur ataupun parameter termodinamika lainnya.

Energi akan berpindah sebagai panas, bila ada beda temperatur diantara sistem dan sekeliling/ diantara dua sistem dan perpindahan ini akan terus berlangsung sampai terjadi kesetimbangan, dimana temperatur kedua sistem sama. Ini terjadi karena sistem dengan temperatur lebih tinggi melepaskan panas sebesar Q dan sistem yang bertemperatur lebih rendah menyerap panas sebesar yang dilepaskan. Dengan demikian kesetimbangan sistem akan terjadibila :

$$
\mathrm{Q}_{\text {lepas }}=\mathrm{Q}_{\text {serap }}
$$

Perpindahan energi sebagai panas tidak hanya dilihat/dipelajari bagaimana energi berpindah dari satu benda/sistem ke benda/sistem yang lain, tetapi yang utama dipelajari bagaimana laju perpindahan energi itu terjadi pada berbagai kondisi. Jadi laju perpindahan energi sebagai panas yang menjadi hal penting untuk dipelajari.

Perpindahan energi sebagai panas dapat berlangsung dalam tiga cara yaitu konduksi, konveksi dan radiasi. Dalam berbagai sistem ataupun siklus perekayasaan, mekanisme perpindahan panas ini tidak berlangsung hanya dengan satu cara saja, tetapi akan berlangsung dengan beberapa cara secara bersamaan. Demikian pula pada berbagai alat penukar kalor, perpindahan energi sebagai panas akan berlangsung tidak hanya dengan satu mekanisme, tetapi beberapa mekanisme secara bersamaan.

\section{Perpindahan Panas Konduksi}


Konduksi adalah satu-satunya mekanisme dengan mana panas dapat mengalir dalam zat padat yang tidak tembus cahaya. Hubungan itu menyatakan bahwa laju aliran panas, $\mathrm{q}_{\mathrm{k}}$ dengan cara konduksi dalam suatu bahan dinyatakan sebagai berikut :

$$
\mathrm{q}_{\mathrm{k}}=-\mathrm{kA}(\mathrm{dT} / \mathrm{dx})
$$

dimana :

k : konduktivitas termal bahan $(\mathrm{W} / \mathrm{mK})$

A : luas penampang tegak lurus arah perpindahan panas $\left(\mathrm{m}^{2)}\right.$

$\mathrm{dT} / \mathrm{dx}$ : laju perubahan temperatur, $\mathrm{T}$ terhadap jarak dalam arah aliran $\mathrm{x}$

$\mathrm{q}_{\mathrm{k}} \quad$ : laju perpindahan panas konduksi (W)

\section{Perpindahan Panas Konveksi}

Konveksi merupakan perpindahan energi antara permukaan benda padat dan cairan atau gas. Laju perpindahan panas dengan cara konveksi antara suatu permukaan dan suatu fluida dapat dihitung dengan persamaan berikut :

dimana :

$$
\mathrm{q}_{\mathrm{c}}=\mathrm{h}_{\mathrm{c}} \mathrm{A} \Delta \mathrm{T}
$$

$\mathrm{q}_{\mathrm{c}} \quad$ : laju perpindahan panas konveksi (W)

A : luas bidang perpindahan panas $\left(\mathrm{m}^{2}\right)$

$\Delta \mathrm{T}$ : beda antara temperatur permukaan dalam pipa, $\mathrm{Ts}$

dan temperatur rata-rata fluida dalam pipa, $\mathrm{T} \infty(\mathrm{K})$

$h_{c} \quad$ : koefisien perpindahan panas konveksi aliran

didalam pipa $\left(\mathrm{W} / \mathrm{m}^{2} \mathrm{~K}\right)$

Mekanisme perpindahan panas gabungan dalam praktekbiasanya pada peralatan mesin seperti penukar kalor, saluran gas buangdan ruang bakar, dimana panas berpindah secara bertahap yang dihubungkan secara seri dan kadang - kadang tiap tahap tergantung dua mekanisme perpindahan panas secara pararel.

\section{Sifataliran (Laminar, transisi atau turbulen)}

Perpindahan panas secara konveksi pada perencanaan ini terjadi pada fluida air dalam pipa air. Untuk mengetahui sifat aliran (laminar, transisi atau turbulen) yang terjadi pada fluida digunakan bilangan Reynold, menurut persamaan berikut :

$$
\operatorname{Re}=\frac{\rho \cdot v \cdot L}{\mu}
$$

Secara umum perpindahan energi sebagai panas (perpindahan panas) dapat berlangsung secara konduksi, konversi dan radiasi. Pada alat penukar kalor (heat exchanger)/APK, Perpindahan panas berlangsung secara konduksi dan konveksi.

Pada alat penukar kalor, keseimbangan energi harus terjadi, yaitu panas yang dilepaskan dari fluida panas sama dengan panas yang diterima oleh fluida dingin.

Menurut prinsip kesetimbangan energi : 
dimana :

$$
\mathrm{Q}_{\mathrm{h}}=\mathrm{Q}_{\mathrm{c}}
$$

$$
\begin{aligned}
& \mathrm{Q}_{\mathrm{h}}=\left(\mathrm{mc}_{\mathrm{p}}\right)_{\mathrm{h}}\left(\mathrm{T}_{\mathrm{h} 1}-\mathrm{T}_{\mathrm{h} 2}\right) \\
& \mathrm{Q}_{\mathrm{c}}=\left(\mathrm{mc}_{\mathrm{p}}\right)_{\mathrm{c}}\left(\mathrm{T}_{\mathrm{c} 1}-\mathrm{T}_{\mathrm{c} 2}\right)
\end{aligned}
$$

Untuk proses perpindahan panas antara fluida dengan suatu permukaan padat, laju perpindahan panas dapat dievaluasi dengan persamaan berikut :

$$
\mathrm{Q}=\mathrm{UA} \Delta \mathrm{T}_{\mathrm{m}}
$$

dimana :

$\mathrm{U} \quad$ : koefisien perpindahan panas menyeluruh $(\mathrm{W} / \mathrm{mK})$

A : luas bidang perpindahan panas $\left(\mathrm{m}^{2}\right)$

$\Delta \mathrm{T}_{\mathrm{m}}$ : beda temperatur rata-rata menyeluruh $(\mathrm{K})$

Pada alat penukar kalor pipa ganda, fluidanya dapat mengalir dalam aliran searah maupun berlawanan arah. Profil temperatur untuk hal ini terlihat pada gambar berikut :

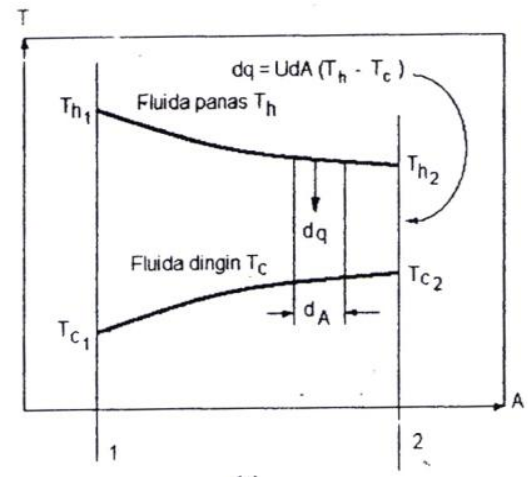

(a)

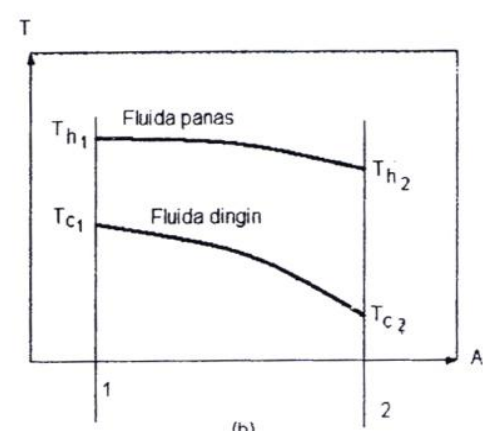

Koefisien Perpindahan Panas Menyeluruh

Untuk menentukan koefisien perpindahan panas menyeluruh dari suatu alat penukar kalor yang baru dirancang digunakan pendekatan berikut :

PendekatanEffectiveness $(\varepsilon)$ - NTU

Effectiveness $(\varepsilon)$ adalah perpindahan kalor nyata dibagi dengan perpindahan maksimum yang mungkin.

* Number of Transfer Unit (NTU) atau bilangan satuan pertukaran panas.

Efektivitas alat penukar kalor didefenisikan sebagai berikut:

$\epsilon=\frac{q}{q \max }=\frac{C h(T h, i n-T h, o u t)}{C \min \left(T h, i n-T c_{,} \text {in }\right)}$

Jurnal Kajian Teknik Mesin

Vol. 1 No. 2 


$$
=\frac{C h\left(T c_{,} \text {in }-T c_{,} \text {out }\right)}{C \min \left(T h, i n-T c_{,} \text {in }\right)}
$$

Dimana : $\mathrm{C}_{\min }$ adalah harga yang paling kecil diantara besaran $\mathrm{C}_{\mathrm{h}}$ atau $\mathrm{C}_{\mathrm{c}}$

\section{Effectiveness=}

$$
\varepsilon=\frac{\text { Perpindahankalor nyata }}{\text { Perpindahan kalor maksikum yang mungkin }}
$$

Perpindahan kalor yang sebenarnya (aktual) dapat dihitung dari energi yang dilepaskan oleh fluida panas atau energi yang diterima oleh fluida dingin.

- Untuk penukar kalor aliran searah:

$$
q=m_{h} c_{h}\left(T_{h 1}-T_{h 2}\right)=m_{c} c_{c}\left(T_{c 2}-T_{c l}\right)
$$

- Untuk penukar kalor aliran lawan arah

$$
q=m_{h} c_{h}\left(T_{h 1}-T_{h 2}\right)=m_{c} c_{c}\left(T_{c l}-T_{c 2}\right)
$$

\section{Pendekatan LMTD}

Perbedaan temperatur rata-rata (LMTD) didefenisikan sebagai menghitung $\Delta \mathrm{T}_{\mathrm{h}-\mathrm{c}}$; karena bervariasi pada saat masuk alat penukar kalor sampai pada seksi keluar alat penukar kalor, temperatur yang terukur hanya pada seksi masuk dan keluar alat penukar kalor.

Untuk fluida aliran searah :

$$
\Delta \mathrm{T}_{\operatorname{lm}}=\frac{(\mathrm{Th} 1-\mathrm{Tc} 1)-(\mathrm{Th} 2-\mathrm{Tc} 2)}{\ln (\mathrm{Th} 1-\mathrm{Tc} 1) /(\mathrm{Th} 2-\mathrm{Tc} 2)} \quad \text { atau } \quad \Delta \mathrm{T}_{\mathrm{lm}}=\frac{\Delta \mathrm{T} 1-\Delta \mathrm{T} 2}{\ln (\Delta \mathrm{T} 1 / \Delta \mathrm{T})}
$$

Beda temperatur ini disebut beda temperatur rata-rata log (log mean temperature difference; LMTD)

Untuk alat penukar kalor pipa ganda, salah satu fluida mengalir dalam tabung yang lebih kecil, sedang fluida yang satu lagi mengalir dalam anulus diantara kedua tabung (Gambar 1). TA dan TB masing-masing adalah temperatur fluida, tapi luas bidang konveksi tidak sama untuk kedua fluida. Luas fluida tergantung dari diameter dalam tabung dan tebal dinding. 

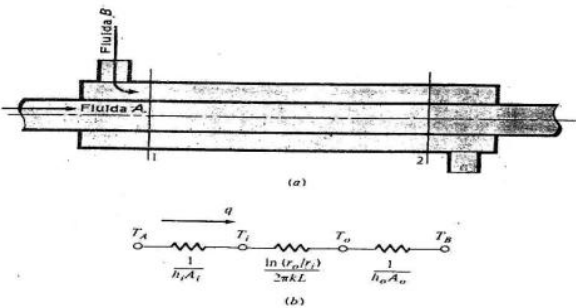

Gambar 1. Perpindahan panas menyeluruh pada penukar kalor pipa ganda

\section{METODE PENELITIAN}

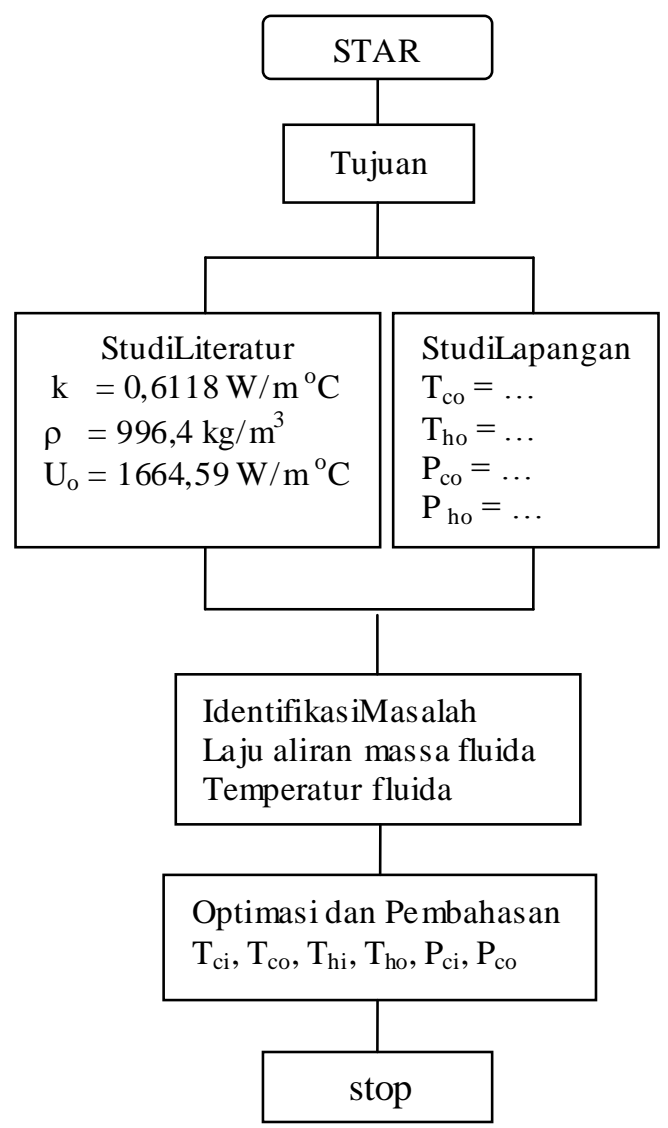

\section{Data Hasil Pengujian}

Pengujian dilakukan dengan berbagai variasi laju aliran fluida dan temperatur fluida panas. Hasil pengujian adalah sebagai berikut (Tabel 1, 2 dan 3):

Tabel 1. Data Hasil Percobaan I

$$
\mathrm{Gh}=\text { konstan }=0,20 \mathrm{~kg} / \mathrm{s}
$$

Jurnal Kajian Teknik Mesin

Vol. 1 No. 2 
Tci $=$ konstan $=30^{\circ} \mathrm{C}$

Thi $=$ konstan $=65^{\circ} \mathrm{C}$

Gh divariasikan : $0,13 \mathrm{~kg} / \mathrm{s} ; 0,20 \mathrm{~kg} / \mathrm{s}$;

$0,27 \mathrm{~kg} / \mathrm{s} ; 0.33 \mathrm{~kg} / \mathrm{s} ; 0.40 \mathrm{~kg} / \mathrm{s}$

Gc divariasikan : $0,13 \mathrm{~kg} / \mathrm{s}$ s/d $0.40 \mathrm{~kg} / \mathrm{s}$

\begin{tabular}{|c|c|c|c|c|c|}
\hline \multirow{2}{*}{ No. } & \multicolumn{5}{|c|}{ HasilPengujian } \\
\cline { 2 - 6 } & $\begin{array}{c}\mathrm{Gc} \\
(\mathrm{Kg} / \mathrm{s})\end{array}$ & $\begin{array}{c}\text { Tci } \\
\left({ }^{\circ} \mathrm{C}\right)\end{array}$ & $\begin{array}{c}\text { Tco } \\
\left({ }^{\circ} \mathrm{C}\right)\end{array}$ & $\begin{array}{c}\text { Thi } \\
\left({ }^{\circ} \mathrm{C}\right)\end{array}$ & $\begin{array}{c}\text { Tho } \\
\left({ }^{\circ} \mathrm{C}\right)\end{array}$ \\
\hline 1 & 0.13 & 30 & 39 & 65 & 59 \\
\hline 2 & 0,20 & 30 & 37 & 65 & 57 \\
\hline 3 & 0,27 & 30 & 36 & 65 & 54 \\
\hline 4 & 0,33 & 30 & 35 & 65 & 52 \\
\hline 5 & 0.40 & 30 & 33 & 65 & 50 \\
\hline
\end{tabular}

$\mathrm{Gc}=$ konstan $=0,20 \mathrm{~kg} / \mathrm{s}$

Tci $=$ konstan $=30{ }^{\circ} \mathrm{C}$

Thi $=$ konstan $=65^{\circ} \mathrm{C}$

Gh divariasikan : 0,13 kg/s; 0,20 kg/s;

$0,27 \mathrm{~kg} / \mathrm{s} ; 0.33 \mathrm{~kg} / \mathrm{s} ; 0.40 \mathrm{~kg} / \mathrm{s}$

\begin{tabular}{|l|c|c|c|c|c|}
\hline \multirow{2}{*}{ No. } & \multicolumn{5}{|c|}{ HasilPengujian } \\
\cline { 2 - 6 } & $\begin{array}{c}\mathrm{Gh} \\
(\mathrm{Kg} / \mathrm{s})\end{array}$ & $\begin{array}{c}\text { Tci } \\
\left({ }^{\circ} \mathrm{C}\right)\end{array}$ & $\begin{array}{c}\text { Tco } \\
\left({ }^{\circ} \mathrm{C}\right)\end{array}$ & $\begin{array}{c}\text { Thi } \\
\left({ }^{\circ} \mathrm{C}\right)\end{array}$ & $\begin{array}{c}\text { Tho } \\
\left({ }^{\circ} \mathrm{C}\right)\end{array}$ \\
\hline 1 & 0.13 & 30 & 33 & 65 & 57 \\
\hline 2 & 0,20 & 30 & 34 & 65 & 59 \\
\hline 3 & 0,27 & 30 & 36 & 65 & 60 \\
\hline 4 & 0,33 & 30 & 37 & 65 & 61 \\
\hline 5 & 0.40 & 30 & 39 & 65 & 62 \\
\hline
\end{tabular}

Tabel 2. Data Hasil Percobaan II

$\mathrm{Gh}=\operatorname{konstan}=0,20 \mathrm{~kg} / \mathrm{s}$

$\mathrm{Tci}=$ konstan $=30{ }^{\circ} \mathrm{C}$

Jurnal Kajian Teknik Mesin

Vol. 1 No. 2 
Thi $=$ konstan $=65{ }^{\circ} \mathrm{C}$

Gc divariasikan : $0,13 \mathrm{~kg} / \mathrm{s}$ s/d $0.40 \mathrm{~kg} / \mathrm{s}$

\begin{tabular}{|c|c|c|c|c|c|}
\hline \multirow{2}{*}{ No. } & \multicolumn{5}{|c|}{ HasilPengujian } \\
\cline { 2 - 6 } & $\begin{array}{c}\mathrm{Gc} \\
(\mathrm{Kg} / \mathrm{s})\end{array}$ & $\begin{array}{c}\text { Tci } \\
\left({ }^{\circ} \mathrm{C}\right)\end{array}$ & $\begin{array}{c}\text { Tco } \\
\left({ }^{\circ} \mathrm{C}\right)\end{array}$ & $\begin{array}{c}\text { Thi } \\
\left({ }^{\circ} \mathrm{C}\right)\end{array}$ & $\begin{array}{c}\text { Tho } \\
\left({ }^{\circ} \mathrm{C}\right)\end{array}$ \\
\hline 1 & 0.13 & 30 & 39 & 65 & 59 \\
\hline 2 & 0,20 & 30 & 37 & 65 & 57 \\
\hline 3 & 0,27 & 30 & 36 & 65 & 54 \\
\hline 4 & 0,33 & 30 & 35 & 65 & 52 \\
\hline 5 & 0.40 & 30 & 33 & 65 & 50 \\
\hline
\end{tabular}

Tabel 3. Data Hasil Percobaan III
$\mathrm{Gc}=$ konstan $=0,20 \mathrm{~kg} / \mathrm{s}$
$\mathrm{Gh}=\operatorname{konstan}=0,20 \mathrm{~kg} / \mathrm{s}$
$\mathrm{Tci}=$ konstan $=30{ }^{\circ} \mathrm{C}$
Thi $=$ divariasikan $=65^{\circ} \mathrm{C} \mathrm{s} / \mathrm{d} 85^{\circ} \mathrm{C}$

\begin{tabular}{|c|c|c|c|c|c|}
\hline \multirow{2}{*}{ No. } & \multicolumn{5}{|c|}{ HasilPengujian } \\
\cline { 2 - 6 } & $\begin{array}{c}\mathrm{Gh} \\
(\mathrm{Kg} / \mathrm{s})\end{array}$ & $\begin{array}{c}\text { Tci } \\
\left({ }^{\circ} \mathrm{C}\right)\end{array}$ & $\begin{array}{c}\text { Tco } \\
\left({ }^{\circ} \mathrm{C}\right)\end{array}$ & $\begin{array}{c}\text { Thi } \\
\left({ }^{\circ} \mathrm{C}\right)\end{array}$ & $\begin{array}{c}\text { Tho } \\
\left({ }^{\circ} \mathrm{C}\right)\end{array}$ \\
\hline 1 & 0.20 & 30 & 39 & 65 & 60 \\
\hline 2 & 0,20 & 30 & 34 & 70 & 65 \\
\hline 3 & 0,20 & 30 & 36 & 75 & 70 \\
\hline 4 & 0,20 & 30 & 38 & 80 & 73 \\
\hline 5 & 0.20 & 30 & 40 & 85 & 79 \\
\hline
\end{tabular}

\section{PERHITUNGAN DAN PEMBAHASAN}

\section{Spesifikasi Alat Penukar Kalor}

Hasil rancangan alat penukar kalor jenis pipa ganda yang diujicobakan memiliki spesifikasi sebagaimana disajikan pada tabel berikut :

Tabel 4. Data Spesifikasi Alat Penukar Kalor

\begin{tabular}{|l|l|l|}
\hline Jenis & & $\begin{array}{l}\text { Alat penukar kalor pipa } \\
\text { ganda }\end{array}$ \\
\hline Ukuran pipa & & \\
\hline Diameter dalam & $D i$ & $17 \mathrm{~mm}(0.017 \mathrm{~m})$ \\
\hline Diameter luar & $D o$ & $19 \mathrm{~mm}(0.019 \mathrm{~m})$ \\
\hline Material pipa & & PipaTembaga \\
\hline
\end{tabular}

Jurnal Kajian Teknik Mesin

Vol. 1 No. 2 


\begin{tabular}{|l|l|l|}
\hline UkuranAnulus & & \\
\hline Diameter dalam & $D i$ & $0.0276 \mathrm{~m}$ \\
\hline Diameter luar & $D o$ & $0.034 \mathrm{~m}$ \\
\hline Material annulus & & Pipabaja 1": SII \\
\hline $\begin{array}{l}\text { Luas total } \\
\text { penampang }\end{array}$ & $A$ & $0,067299 \mathrm{~m}^{2}$ \\
\hline
\end{tabular}

\section{Data Hasil Pengujian}

Setelah melakukan pengujian maka didapat beberapa parameter termodinamika. Sesuai tujuan penelitian yaitu untuk menentukan nilai koefisien perpindahan panas menyeluruh dari alat penukar kalor jenis pipa ganda, maka sebelum melakukan perhitungan perlu dilengkapi parameter termodinamika lainnya sesuai kepustakaan.

Pengujian dilaksanakan dengan pola aliran fluida searah (Uni Flow), dengan fluida kerja air; baik untuk fluida dingin maupun fluida panas (Lampiran 3).

Parameter termodinamika yang dibutuhkan dalam perhitungan untuk menentukan koefisien perpindahan panas seluruh (U) disajikan dalam Lampiran 4, 5 dan 6.

\section{Menentukan Nilai Koefisien Perpindahan Panas Menyeluruh (U)}

Untuk menetukan nilai koefisien perpindahan panas menyeluruh (U) digunakan dua metode yaitu :

\section{Metode LMTD}

2.Metode $\varepsilon$ - NTU

Sebelum melakukan perhitungan koefisien perpindahan panas menyeluruh (U) dengan kedua metode tersebut diatas maka ada beberapa parameter yang harus dihitung terlebih dahulu.

\section{Jumlah Kalor pada Fluida Panas dan Fluida Dingin}

Beban kalor yang diperlukan oleh alat penukar kalor jenis pipa ganda didapat dengan menggunakan persamaan berikut :

$$
\mathrm{q}=\mathrm{m}_{\mathrm{h}} \mathrm{c}_{\mathrm{h}}\left(\mathrm{T}_{\mathrm{hi}}-\mathrm{T}_{\mathrm{ho}}\right)=\mathrm{m}_{\mathrm{c}} \mathrm{c}_{\mathrm{c}}\left(\mathrm{T}_{\mathrm{co}}-\mathrm{T}_{\mathrm{ci}}\right)
$$

dari persamaan diatas maka didapatkan temperatur rata-rata fluida panas, yaitu :

$$
\begin{aligned}
& T h=\frac{T h i+T h o}{2} \\
& T h=\frac{65+57}{2}=61^{\circ} \mathrm{C}
\end{aligned}
$$

Karakteristik fluida pada temperatur $61{ }^{\circ} \mathrm{C}$ adalah sebagai berikut :

$$
\begin{aligned}
\rho & =980 \mathrm{~kg} / \mathrm{m}^{3} \\
\mathrm{cp} & =4284,25 \mathrm{~J} / \mathrm{kg}^{\circ} \mathrm{C} \\
\mathrm{k} & =0,659 \mathrm{~W} / \mathrm{m}^{\circ} \mathrm{C} \\
\mathrm{Pr} & =3,04 \\
\mathrm{Gm} & =12 \mathrm{l} / \mathrm{mnt}
\end{aligned}
$$

Maka laju aliran massa pada sisi anulus pada temperatur $61^{\circ} \mathrm{C}$ adalah : 


$$
\begin{aligned}
\mathrm{mh} & =\rho \mathrm{Gv} \\
& =980 \mathrm{~kg} / \mathrm{m}^{3} \times 0,133 \times 10^{-3} \mathrm{~m}^{3} / \mathrm{s} \\
& =0,13 \mathrm{~kg} / \mathrm{s}
\end{aligned}
$$

Laju aliran massa pada sisi pipa adalah

$$
\mathrm{mc}=\rho \mathrm{Gv}
$$

dimana :

$$
\begin{aligned}
\rho & =995,7 \mathrm{~kg} / \mathrm{m}^{3} \\
\mathrm{Gm} & \left.=121 / \mathrm{min}=0,20 \cdot 10^{-3} \mathrm{~m}^{3} / \mathrm{s}\right) \\
\mathrm{maka} & : \\
\mathrm{mc} & =995,7 \mathrm{~kg} / \mathrm{m}^{3} \times 0,20 \cdot 10^{-3} \mathrm{~m}^{3} / \mathrm{s} \\
& =0,20 \mathrm{~kg} / \mathrm{s}
\end{aligned}
$$

Setelah parameter - parameter tersebut diatas didapat, maka jumlah kalor pada sisi anulus dan pipa dapat dihitung.

\section{Jumlah kalor pada sisi anulus, Qh}

$$
\mathrm{Qh}=(\mathrm{mcp}) \mathrm{h}\left(\mathrm{T}_{\mathrm{hi}}-\mathrm{Th}_{\mathrm{o}}\right)
$$

dimana :

cp : panas jenis fluida panas pada tekanan konstan $\left(\mathrm{J} / \mathrm{kg}^{\circ} \mathrm{C}\right)$

$\mathrm{T}_{\mathrm{hi}}$ : temperatur fluida masuk anulus $\left({ }^{\circ} \mathrm{C}\right)$

$\mathrm{T}_{\text {ho }}$ : temperatur fluida keluar anulus $\left({ }^{\circ} \mathrm{C}\right)$

maka :

berdasarkan data pengujian :

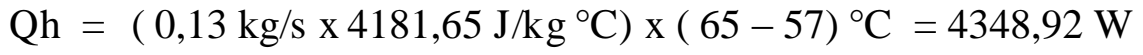

berdasarkan data hasil perhitungan adalah :

$$
\begin{aligned}
\mathrm{Qh} & =\left(0,13 \mathrm{~kg} / \mathrm{s} \mathrm{x} 4181,65 \mathrm{~J} / \mathrm{kg}^{\circ} \mathrm{C}\right) \times \quad(65-60,38){ }^{\circ} \mathrm{C} \\
& =2511,499 \mathrm{~W}
\end{aligned}
$$

\section{Jumlah Kalor Pada Sisi Pipa, Qc}

Qc $=(\operatorname{mcp}) \mathrm{c}\left(\mathrm{T}_{\mathrm{co}}-\mathrm{T}_{\mathrm{ci}}\right)$

dimana :

cp : panas jenis fluida dingin pada tekanan konstan $\left(\mathrm{J} / \mathrm{kg}^{\circ} \mathrm{C}\right)$

$\mathrm{T}_{\mathrm{ci}}$ : temperatur fluida masuk pipa $\left({ }^{\circ} \mathrm{C}\right)$

$\mathrm{T}_{\text {co }}$ : temperatur fluida keluar pipa $\left({ }^{\circ} \mathrm{C}\right)$

maka :

berdasarkan data pengujian :

$$
\mathrm{Qc}=\left(0,20 \mathrm{~kg} / \mathrm{s} \mathrm{x} 4185 \mathrm{~J} / \mathrm{kg}{ }^{\circ} \mathrm{C}\right) \times\left(\mathrm{T}_{\mathrm{co}}-30\right){ }^{\circ} \mathrm{C}
$$

Untuk mendapatkan nilai Qc, maka perlu diketahui nilai $\mathrm{T}_{\mathrm{co}}$

Untuk mendapatkan nilai $\mathrm{T}_{\mathrm{co}}$ digunaka persamaan berikut :

$\mathrm{Qc}=\mathrm{Qh}=(\mathrm{mcp}) \mathrm{c}\left(\mathrm{T}_{\mathrm{co}}-\mathrm{T}_{\mathrm{ci}}\right)$

$4348,92 \mathrm{~J} / \mathrm{s}=\left(0,20 \mathrm{~kg} / \mathrm{s} \times 4185 \mathrm{~J} / \mathrm{kg}^{\circ} \mathrm{C}\right)\left(\mathrm{T}_{\mathrm{co}}-30\right){ }^{\circ} \mathrm{C}$ 


$$
\mathrm{T}_{\mathrm{co}}=\frac{4348,92 \frac{\mathrm{J}}{g}+\left(0,20 \frac{\mathrm{kg}}{\mathrm{g}} \times 4185 \mathrm{~J} / \mathrm{kg} g^{8} \mathrm{C}\right) \times 30^{\circ} \mathrm{C}}{0,20 \frac{\mathrm{kg}}{g} \times 4185 \mathrm{~J} / \mathrm{kg} \mathrm{g}^{8} \mathrm{C}}=35,196^{\circ} \mathrm{C}
$$

Setelah $\mathrm{T}_{\mathrm{co}}$ didapat, maka Qc (sesuai hasil pengukuran) dapat dihitung :

$$
\mathrm{Qc}=\left(0,20 \mathrm{~kg} / \mathrm{s} \times 4185 \mathrm{~J} / \mathrm{kg}{ }^{\circ} \mathrm{C}\right) \times(33-30){ }^{\circ} \mathrm{C}=2511 \mathrm{~W}
$$

Sedangkan Qc sesuai perhitungan adalah sebagai berikut :

$$
\mathrm{Qc}=\left(0,20 \mathrm{~kg} / \mathrm{s} \times 4185 \mathrm{~J} / \mathrm{kg}^{\circ} \mathrm{C}\right) \times(35,196-30){ }^{\circ} \mathrm{C}=4349,05 \mathrm{~W}
$$

Jadi temperatur rata - rata fluida dingin adalah :

$$
T c r=\frac{T c i+T c o}{2} ; T c r=\frac{30+33,86}{2}=32,598^{\circ} \mathrm{C}
$$

Karakteristik fluida pada temperatur $32,598^{\circ} \mathrm{C}$ adalah sebagai berikut :

$$
\begin{aligned}
\rho & =995,25 \mathrm{~kg} / \mathrm{m}^{3} \\
\mathrm{cp} & =4177,8 \mathrm{~J} / \mathrm{kg}^{\circ} \mathrm{C} \\
\mathrm{k} & =0,6184 \mathrm{~W} / \mathrm{m}^{\circ} \mathrm{C} \\
\operatorname{Pr} & =5,912
\end{aligned}
$$

\section{Perhitungan Nilai Koefisien Perpindahan Panas Menyeluruh (U) Dengan Menggunakan Metode LMTD}

Koefisien perpindahan panas menyeluruh, $\mathrm{U}$ dapat dihitung dengan menggunakan persamaan berikut :

dimana :

$$
\mathrm{Q}=\mathrm{U} \cdot \mathrm{A} \cdot \mathrm{LMTD}
$$

$\mathrm{Q}:$ beban kalor $=4348,92 \mathrm{~J} / \mathrm{s}$

A : luas total penampang $=0,067299 \mathrm{~m}^{2}$

LMTD : beda temperatur rata-rata

Dari persamaan diatas, maka koefisien perpindahan panas menyeluruh, $U$ adalah :

$$
\begin{gathered}
U=\frac{Q}{A x L M T D} \\
L M T D=\frac{(T h i-T c i)-(T h o-T c o)}{\ln \left[\frac{T h i-T \sigma i}{T h o-T c o}\right]}
\end{gathered}
$$

dimana :

Thi : temperatur fluida panas masuk anulus $=65^{\circ} \mathrm{C}$

Tho: temperatur fluida panas keluar anulus $=57^{\circ} \mathrm{C}$

Tci : temperatur fluida dingin masuk pipa $=30^{\circ} \mathrm{C}$

Tco : temperatur fluida dingin keluar pipa $=33{ }^{\circ} \mathrm{C}$

maka :

$$
\text { LMTD }=\frac{(65-30)-(57-33)}{\ln [65-30) /(57-33)]}=29,15^{\circ} \mathrm{C}
$$


sehingga :

$$
\mathrm{U}=\frac{4348,92}{0,067299 \times 29,15}=2692,54 \mathrm{~W} / \mathrm{m}^{2 \circ} \mathrm{C}
$$

\section{Perhitungan Koefisien Perpindahan Panas Menyeluruh Dengan Menggunakan Metode} $\varepsilon-\mathbf{N T U}$

Koefisien perpindahan panas menyeluruh dapat dihitung dengan menggunakan persamaan berikut :

$$
U=\frac{N T U x C \min }{A}
$$

dimana :

$$
N T u=-\frac{1}{1+C} \ln [1+\varepsilon(1+C]
$$

$\varepsilon:$ efektivitas penukar kalor (heat exchanger effectiveness)

$$
\varepsilon=\frac{T h i-T h o}{T h i-T c i}=\frac{65-57}{65-30}=0,229
$$

$\mathrm{R}$ : laju kapasitas panas ; $\mathrm{R}=\frac{C \min }{C_{\max }}$

bila $\mathrm{C}_{\mathrm{h}}>\mathrm{C}_{\mathrm{c}}$;

maka

$\mathrm{C}_{\mathrm{h}}=\mathrm{C}_{\max } \quad$ dan $\mathrm{C}_{\mathrm{c}}=\mathrm{C}_{\min } \mathrm{C}_{\mathrm{c}}>\mathrm{C}_{\mathrm{h}}$;

maka

$\mathrm{C}_{\mathrm{c}}=\mathrm{C}_{\max }$ dan $\mathrm{C}_{\mathrm{h}}=\mathrm{C}_{\mathrm{min}}$

dimana :

$$
\begin{aligned}
\mathrm{C}_{\mathrm{c}} & =\mathrm{mc} \cdot \mathrm{cpc} \\
& =0,20 \mathrm{~kg} / \mathrm{s} \times 4185 \mathrm{~J} / \mathrm{kg}^{\circ} \mathrm{C} \\
\mathrm{C}_{\mathrm{c}} & =837 \mathrm{~W} /{ }^{\circ} \mathrm{C} \\
\mathrm{C}_{\mathrm{h}} & =\mathrm{m}_{\mathrm{h}} \cdot \mathrm{cp}_{\mathrm{h}} \\
& =0,13 \mathrm{~kg} / \mathrm{s} \times 4181,35 \mathrm{~J} / \mathrm{kg}^{\circ} \mathrm{C} \\
\mathrm{C}_{\mathrm{h}} & =543,576 \mathrm{~W} /{ }^{\circ} \mathrm{C}
\end{aligned}
$$

maka :

$$
\mathrm{C}_{\mathrm{c}} \text { adalah } \mathrm{C}_{\max } \text { dan }
$$

Jurnal Kajian Teknik Mesin

Vol. 1 No. 2 


$$
\mathrm{C}_{\mathrm{h}} \text { adalah } \mathrm{C}_{\min }
$$

Sehingga :

$$
\mathrm{R}=\frac{543,576 W / /^{\circ} C}{837 W / /^{\circ} C}=0,649 \mathrm{~W} /{ }^{\circ} \mathrm{C}
$$

Dengan demikian maka nilai NTU adalah :

$$
N T u=-\frac{1}{1+0,649} \ln [1+0,229(1+0,649]=0,194
$$

Setelah nilai NTU didapat, maka nilai koefisien perpindahan panas menyeluruh, U dapat dihitung :

$$
\mathrm{U}=\frac{N T \cdot \cdot C \min }{A}=\frac{0,194 \times 543,576 \mathrm{~W} /{ }^{2} \mathrm{C}}{0,067299 \mathrm{~m}^{2}}=1566,944 \mathrm{~W} / \mathrm{m}^{2}{ }^{\circ} \mathrm{C}
$$

Selanjutnya dengan cara yang sama dan yang menggunakan metode LMTD dan NTU, nilai koefisien perpindahan panas menyeluruh didapat untuk berbagai variasi temperatur dan laju aliran masuk fluida panas maupun fluida dingin.

Untuk temperatur fluida dingin dan laju aliran masuk fluida dingin konstan dan temperatur fluida panas masuk serta laju aliran masuk bervariasi, maka bila menggunakan metode LMTD, nilai koefisien perpindahan panas menyeluruh (U) meningkat, demikian pula bila menggunakan metode NTU, U juga meningkat.

Untuk laju alir massa fluida dingin bervariasi, laju aliran masuk fluida panas konstan dan temperatur fluida panas bervariasi; maka nilai koefisien perpindahan panas menyeluruh dengan menggunakan metode LMTD menurun (berbanding terbalik dengan temperatur fluida panas), demkian pula bila menggunakan metode NTU, U menurun sehubungan dengan peningkatan temperatur fluida panas.

Untuk laju aliran masuk fluida dingin konstan dan temperatur fluida panas konstan sedangkan laju aliran masuk fluida panas bervariasi, maka koefisien perpindahan panas menyeluruh (U) menurut metode LMTD maupun NTU meningkat cukup signifikan.

Untuk temperatur fluida panas masuk dan laju aliran masuk fluida panas konstan serta laju aliran masuk fluida dingin bervariasi, maka nilai koefisien perpindahan panas menyeluruh baik dengan menggunakan metode LMTD maupun metode NTU mengalami penurunan.

Perbandingan Hasil Pengujian dan Perhitungan dengan Hasil desain dan Hasil Pengujian Sebelumnya.

Setelah melakukan pengujian dan perhitungan terhadap alat penukar kalor jenis pipa ganda, maka hasil ini perlu dibandingkan dengan hasil desain serta hasil pengujian sebelumnya yang menggunakan jenis aliran berlawanan. Pengujian yang dilaksanakan menggunakan pola aliran searah. Data perbandingan disajikan pada tabel berikut : 


\begin{tabular}{|l|c|c|c|}
\hline Parameter & $\begin{array}{c}\text { Data } \\
\text { desain }\end{array}$ & $\begin{array}{c}\text { Pengujian: Aliran } \\
\text { Lawan }\end{array}$ & Pengujian Searah \\
\hline $\begin{array}{l}\text { Beban Kalor (Q), } \\
(W)\end{array}$ & 4772.62 & 2229.62 & 5019 \\
\hline $\begin{array}{l}\text { Rasio Kapasitas } \\
\text { Panas (R) }\end{array}$ & 0.376 & 0.372 & 0.5 \\
\hline Efektivitas $(\varepsilon)$ & 0.157 & 0.105 & 0.100 \\
\hline LMTD & 45.45 & 45.45 & 28.66 \\
\hline $\mathrm{NTU}$ & 0.176 & & 0.1 \\
\hline $\mathrm{U},\left(\mathrm{W} / \mathrm{m}^{20} \mathrm{C}\right)$ & 1190.05 & 1644.09 & 1814 \\
\hline
\end{tabular}

\section{KESIMPULAN DAN SARAN}

\section{Kesimpulan}

Dari hasil pengujian dan perhitungan, maka dapat disimpulkan beberapa hal berikut :

1. Panas yang diserap fluida tidak sepenuhnya dilepas/dibuang, ini terlihat dari beda temperatur yang keluar annulus dan yang keluar pipa.

2. Kondisi optimal yang dicapai adalah pada percobaan ketiga dimana koefisien perpindahan panas menyeluruh (U) yang didapat dengan menggunakan metode LMTD adalah $3024 \mathrm{~W} / \mathrm{m}^{2}{ }^{\circ} \mathrm{C}$, dengan aliran fluida masuk pipa $(\mathrm{Gvc})=20 \mathrm{ltr} / \mathrm{mnt}$; Tci $=30{ }^{\circ} \mathrm{C}$; Tco $=35^{\circ} \mathrm{C}$; Thi $=75^{\circ} \mathrm{C}$ dan Tho $=70^{\circ} \mathrm{C}$. Dan dengan menggunakan metode NTU adalah $1814 \mathrm{~W} / \mathrm{m}^{2}{ }^{\circ} \mathrm{C}$; dengan $\mathrm{Gvc}=12 \mathrm{ltr} / \mathrm{mnt} ; \mathrm{Tci}=30{ }^{\circ} \mathrm{C}$;

Tco $=35^{\circ} \mathrm{C}$ Thi $=70^{\circ} \mathrm{C}$ dan $\mathrm{Tho}=65^{\circ} \mathrm{C}$

\section{Saran}

Dari hasil perhitungan yang dilakukan didapati adanya sejumlah panas yang hilang. Sehubungan dengan hal tersebut (panas yang hilang), maka disarankan untuk menggunakan isolasi sesuai hasil perhitungan.

\section{DAFTAR PUSTAKA}

1. Cengel Y A, Boles MA. 2007. Thermodynamics an engineering approach, Sixth Edition in SI Units. Singapore: Mc Graw Hill

2. Kreith F, Black, W Z. 1980. Basic Heat Transfer. New York. Harper \& Row

3. Moran JM, Shapiro NH, 1988. Fundamental of Engineering Thermodynamics. New York: John Willey \& Son, Inc

4. Stocker WF. 1989. Design of Analysis of Thermal Sistem. New York. McGraw-Hill, Inc

5, Yogesh Jaluria. Design and Optimazation of Thermal Sistem. New York. CRC Press and Taylor\&FrancesGroup 